\title{
The Assay, Extraction and Storage of Infective Ribonucleic Acid from Foot and Mouth Disease Virus
}

\author{
BY JOAN CRICK, A. I. LEBEDEV, DOREEN L. STEWART AND F. BROWN \\ Animal Virus Research Institute, Pirbright, Woking, Surrey
}

(Received 13 September 1965)

\begin{abstract}
SUMMARY
A plaque assay method is described for the titration of the infective ribonucleic acid (RNA) of foot-and-mouth disease (FMD) virus. The method depends on the dilution of the RNA in salt solutions of high molarity and the treatment of the BHK 21 cell monolayers used with $\mathrm{M}-\mathrm{NaCl}$. The method is reproducible and is at least as sensitive as other methods of titration. The extraction of RNA in the presence of EDTA gave titres corresponding to $0.1 \%$ of the titre of the intact virus. RNA prepared from virus suspensions containing EDTA retained about $50 \%$ of initial infectivity for 7 days at $4^{\circ}$ but for longer periods it was best preserved in $\mathbf{7 0} \%(\mathrm{v} / \mathrm{v})$ ethanol at $-20^{\circ}$.
\end{abstract}

\section{INTRODUCTION}

In any detailed study of the structure and multiplication of RNA viruses the methods used for the isolation and titration of the infective RNA are most important. With two exceptions, all the methods described for the titration of the RNA from FMD virus have given titres which varied between 0.1 and $0.001 \%$ of the corresponding virus titre. In the first descriptions of the extraction of RNA from FMD virus (Brown, Sellers \& Stewart, 1958; Mussgay \& Strohmaier, 1958; Brown \& Stewart, 1959), values of this order were obtained when the RNA was extracted with cold phenol and titrated by intramuscular or intracerebral inoculation of suckling mice or by observing the cytopathic effect (CPE) of the extract on pig kidney cell monolayers (Brown \& Stewart, 1959). Hantschel (1963) and Hantschel \& Veckenstedt (1964) also obtained similar RNA titres by intracerebral inoculation of mice. In 1960 Bachrach described a plaque assay method using calf kidney cell monolayers in which the highest RNA titres were only of the order of $0.001 \%$ of those obtained with the virus. These values were of a similar order to those obtained for several other animal viruses. There were, however, two reports in which the titre of the RNA from FMD virus was considerably higher than those referred to above. Thomas \& Leclerc (1959) claimed a very high titre in guinea pigs (namely, $10 \%$ of that of the virus) for RNA extracted from guinea-pig or cattle virus, although they later reported (Thomas \& Leclerc, 1960) that the titre was more usually of the order of $0.3 \%$. Thely et al. (1961) claimed that the titre of RNA in cattle was $88 \%$ of that for the cattle virus from which it was prepared but it would seem wise to accept this exceptionally high titre with caution, especially as it would be almost impossible to preclude the presence of traces of ribonuclease in the method of titration used. 
In many experiments over a number of years we had been unable to develop a plaque technique for the titration of FMD-virus RNA in pig kidney cells. Following the demonstration by Mowat \& Chapman (1962) that BHK 21 cells are susceptible to FMD virus, the suitability of these cells for the assay of RNA was examined. As with pig kidney cells, very few plaques were obtained when the RNA was added in isotonic solution. When the cell sheets were washed with hypertonic solutions before the addition of the RNA (Koch, Koenig \& Alexander, 1960) or the RNA was diluted in hypertonic solution (Alexander, Koch, Mountain \& van Damme, 1958; Koch et al. 1960; Holland, Hoyer, McLaren \& Syverton, 1960), more plaques were formed. These observations led us to make a more detailed study of the optimal conditions for plaque formation. In the present paper we also include experiments designed to improve the extraction and stability of RNA from FMD virus.

\section{METHODS}

Virus strains. Foot-and-mouth disease (FMD) virus strains of immunological types 0 (strain 1) and SAT 1 (strain Turkey 43/62) were used. The strains were maintained by passage in guinea pigs and in BHK 21 cells (Macpherson \& Stoker, 1962). Virus from guinea pigs was collected as epithelium and vesicular fluid from the hind pads $24-48 \mathrm{hr}$. after infection and stored at $-20^{\circ}$ until required. The culture virus was collected as the supernatant fluid from cell monolayers incubated in Eagle's medium.

Extraction of $R N A$. Virus suspensions at $4^{\circ}$ were shaken with an equal volume of phenol which had been equilibrated with one of the following: (a) 0.01 M- or 0.04 M-phosphate (pH 7.6); (b) $\mathrm{H}_{2} \mathrm{O} ;(c)$ 0.04 M-phosphate ( $\mathrm{pH} \mathrm{7.6)} \mathrm{containing}$ M-NaCl; (d) 0.04 M-phosphate or $\mathrm{H}_{2} \mathrm{O}$ containing $0.01 \%$ sodium ethylenediaminetetraacetate (EDTA). The two layers were separated by centrifugation at 2000 rev./ min. for 2 min. and the aqueous layer extracted a second time with phenol. The phenol was removed from the aqueous layer by two or more extractions with redistilled ether and the dissolved ether removed in a stream of nitrogen. Each RNA extract was adjusted to $\mathrm{pH} 7 \cdot 4-7 \cdot 6$ immediately after removal of the ether and, because of the stabilizing effect of $\mathrm{M}-\mathrm{NaCl}$ on FMD-virus RNA (Thomas \& Leclerc, 1959, 1960) and in view of our own results, this reagent was usually added. In some experiments $\mathrm{M}-\mathrm{NaCl}, 0.01 \%$ EDTA or $0.1 \%$ sodium dodecyl sulphate (SDS) in 0.04 M-phosphate ( $\mathrm{pH} \mathrm{7.6)}$ or bentonite was added to the virus suspension before phenol extraction.

Titration of virus. Most virus assays were made by the plaque technique in BHK 21 cell monolayers (Mowat \& Chapman, 1962). As an alternative, tenfold dilutions of the virus suspensions were inoculated intracerebrally into groups of suckling mice (Skinner, 1951) and the end points calculated by the method of Reed \& Muench (1938). A few assays were made in guinea pigs by intradermal inoculation of the hind pads and the end points calculated in the same way.

Titration of $\boldsymbol{R N A}$. Infective RNA was assayed in animals or in cultured cells. For the animal tests tenfold dilutions in phosphate buffered saline (PBS) were inoculated intracerebrally into suckling mice or intradermally into the hind pads of guinea pigs. The RNA was also assayed by observing the cytopathic effect (CPE) produced in monolayers of BHK 21 cells. In these experiments care was taken to wash the 
sheets of cells free from serum before adding the RNA but it was unnecessary to use hypertonic conditions. All washes were made with phosphate buffered saline (PBS) and the cell sheets incubated in Eagle's medium after the adsorption of the RNA. The monolayers were examined for CPE up to 72-96 hr after infection. The CPE led finally to the monolayers stripping from the glass.

RNA was also assayed by the plaque technique in BHK21 cells by the method developed in this work. It was again essential to wash the cells free from serum. The cell monolayers were therefore washed twice with PBS and then once with $\mathrm{M}-\mathrm{NaCl}$ in 0.04 M-phosphate ( $\mathrm{pH} 7 \cdot 6)$. This last solution was left on the monolayers for

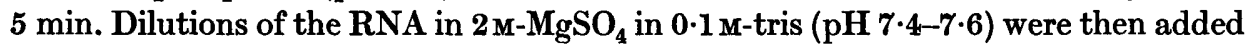
and allowed to adsorb for $20 \mathrm{~min}$. at $15-20^{\circ}$. After a final wash with PBS the monolayers were overlaid with agar made up in Eagle medium containing $10 \%$ ox serum and incubated at $37^{\circ}$. After $24-48 \mathrm{hr}$ the cell sheets were stained with $1 / 10,000$ neutral red to reveal plaques. An alternative method which we have found convenient is to fix the monolayers with buffered formalin $(4 \%, \mathrm{w} / \mathrm{v}, \mathrm{HCHO}$ in PBS) at room temperature and up to $48 \mathrm{hr}$ later remove the agar and stain with methylene blue. The most reproducible results were obtained with monolayers which had been grown for 24-48 hr. Monolayers older than this were less sensitive and were more easily detached from the glass by the repeated washings required in the assay. This detachment was particularly noticeable when polystyrene Petri dishes were used.

\section{RESULTS \\ Plaque assay for $R N A$}

Since cells vary in their susceptibility to injury by hypertonic solutions (Koch et al. 1960; Sprunt, Koenig \& Alexander, 1961), the ability of BHK monolayers to survive such treatment was first examined. The RNA titres following the use of different washing procedures and diluents for the RNA were then compared. The length of time required for pre-treatment of the monolayers was ascertained and the optimal time for RNA adsorption determined. Other factors, including the volume and $\mathrm{pH}$ of the inoculum, were also considered. When the best conditions had been found, the method was checked for reproducibility and the dose-response relationship determined. Finally, the assay was compared with other titration methods for RNA.

We found that BHK cells withstood treatment with hypertonic solutions provided that the time of contact was not excessive. Severe damage was caused when the monolayers were exposed to $\mathrm{M}-\mathrm{NaCl}$ or $2 \mathrm{M}-\mathrm{MgSO}_{4}$ for longer than $30 \mathrm{~min}$. Since increased damage occurred at $37^{\circ}$ without any increase in the number of plaques (see Holland et al. 1960), the washing of cell monolayers and adsorption of RNA were always done at $15-20^{\circ}$.

Monolayers were washed $\mathbf{3}$ times to remove serum before the addition of RNA but the solution used for the third wash was varied. Very few plaques were obtained unless the final wash was made with a strong salt solution or the RNA was diluted in a solution of high molarity (Table 1, Expt. 1). The highest titres and least cell damage were obtained when the final wash was $\mathrm{M}-\mathrm{NaCl}$ and the diluent for the RNA contained $2 \mathrm{M}-\mathrm{MgSO}_{4}$ (Table 1, Expts. 1-3).

Montagnier \& Sanders (1962) obtained higher titres for encephalomyocarditis 
virus RNA by subjecting the cells to hypotonic shock before adding the RNA in hypotonic solution, but the results in Table 1, Expt. 4, show that this technique was not applicable to our system.

However, pre-treatment of the monolayers with $\mathrm{M}-\mathrm{NaCl}$ for periods varying between 1 and $15 \mathrm{~min}$. did not alter the number of plaques subsequently developed and a standard time of $5 \mathrm{~min}$. was found to be the most convenient.

Table 1. Effect of diluent and pre-treatment of BHK monolayers on the titration of FMD-virus RNA. RNA extractions made with phenol saturated with $0.04{ }_{M-P O}, p H ~ 7 \cdot 6$

\begin{tabular}{|c|c|c|c|}
\hline Experiment & Diluent for RNA* & Pre-treatment & Titre (p.f.u./ml. \\
\hline 1. & 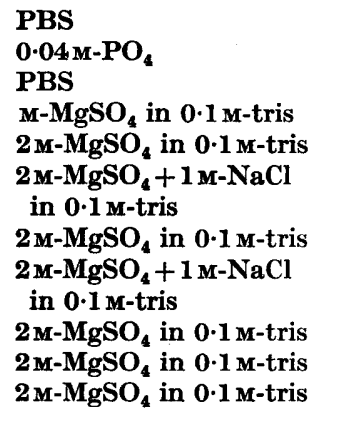 & 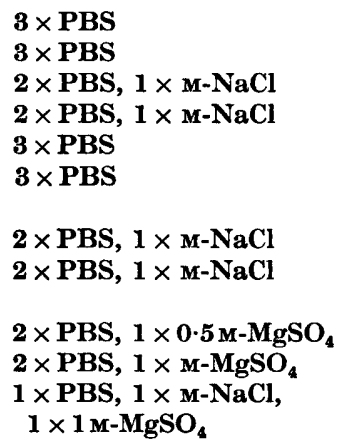 & $\begin{array}{l}2 \cdot 0 \\
0 \\
2 \cdot 6 \times 10^{4} \\
1 \cdot 0 \times 10^{4} \\
2 \cdot 6 \times 10^{4} \\
2 \cdot 7 \times 10^{4} \\
\\
2 \cdot 3 \times 10^{5} \\
2 \cdot 8 \times 10^{5} \\
\\
5 \cdot 0 \times 10^{3} \\
2 \cdot 5 \times 10^{4} \\
5 \cdot 0 \times 10^{3}\end{array}$ \\
\hline 2 & $\begin{array}{l}2 \mathrm{M}-\mathrm{MgSO}_{4} \text { in } 0 \cdot 1 \mathrm{M} \text {-tris } \\
2 \mathrm{M}-\mathrm{NaCl} \text { in } 0 \cdot 04 \mathrm{M}-\mathrm{PO}_{4} \\
\mathrm{M}-\mathrm{NaCl} \text { in } 0 \cdot 04 \mathrm{M}^{-\mathrm{PO}_{4}} \\
2 \mathrm{M} \text {-sucrose in } 0 \cdot 04 \mathrm{M}-\mathrm{PO}_{4}\end{array}$ & $\begin{array}{l}2 \times \text { PBS, } 1 \times \mathrm{M}-\mathrm{NaCl} \\
2 \times \text { PBS, } 1 \times \mathrm{M}-\mathrm{NaCl} \\
2 \times \text { PBS, } 1 \times \mathrm{M}-\mathrm{NaCl} \\
2 \times \text { PBS, } 1 \times \mathrm{M}-\mathrm{NaCl}\end{array}$ & $\begin{array}{l}1.9 \times 10^{5} \\
1.5 \times 10^{5} \\
1.9 \times 10^{5} \\
6.6 \times 10^{4}\end{array}$ \\
\hline $\mathbf{3}$ & $\begin{array}{l}2 \mathrm{M} \text {-sucrose in } 0 \cdot 04 \mathrm{M}-\mathrm{PO}_{4} \\
2 \mathrm{M} \text {-sucrose in } 0 \cdot 04 \mathrm{M}-\mathrm{PO}_{4} \\
\mathrm{M}-\mathrm{NaCl} \text { in } 0.04 \mathrm{M}-\mathrm{PO}_{4} \\
\mathrm{M}-\mathrm{NaCl} \text { in } 0.04 \mathrm{M}-\mathrm{PO}_{4}\end{array}$ & $\begin{array}{l}2 \times \text { PBS, } 1 \times \mathrm{M}-\mathrm{NaCl} \\
3 \times \text { PBS } \\
2 \times \text { PBS, } 1 \times \mathrm{M}-\mathrm{NaCl} \\
\mathbf{3} \times \mathbf{P B S}\end{array}$ & $\begin{array}{l}8.9 \times 10^{3} \\
6 \cdot 2 \times 10^{2} \\
1 \cdot 6 \times 10^{4} \\
2 \cdot 0 \times 10^{3}\end{array}$ \\
\hline 4 & $\begin{array}{l}2 \mathrm{M}-\mathrm{MgSO}_{4} \text { in } 0.1 \mathrm{M} \text {-tris } \\
2 \mathrm{M}-\mathrm{MgSO}_{4} \text { in } 0 \cdot 1 \mathrm{M} \text {-tris } \\
2 \mathrm{M}-\mathrm{MgSO}_{4} \text { in } 0.1 \mathrm{M} \text {-tris } \\
2 \mathrm{M}-\mathrm{MgSO}_{4} \text { in } 0 \cdot 1 \mathrm{~m} \text {-tris }\end{array}$ & $\begin{array}{l}2 \times \text { PBS, } 1 \times \mathrm{M}-\mathrm{NaCl} \\
3 \times \text { PBS } \\
2 \times \text { PBS, } 1 \times 10 \% \text { PBS } \\
1 \times \text { PBS, } 1 \times 10 \% \text { PBS, } \\
1 \times \mathrm{M}-\mathrm{NaCl}\end{array}$ & $\begin{array}{l}1.0 \times 10^{5} \\
1.8 \times 10^{3} \\
1 \cdot 0 \times 10^{2} \\
5 \cdot 0 \times 10^{4}\end{array}$ \\
\hline
\end{tabular}

The initiation of infection by the RNA of FMD virus appears to be rapid (see Bachrach, 1960) and there was little increase in the number of plaques formed after the first few minutes of adsorption. As a routine the time allowed for adsorption was 15-20 min. since this allowed several titrations to be made consecutively. It was also advantageous to wash the monolayers with PBS following adsorption of the RNA since failure to do this often led to tearing of the cell sheet.

Throughout these experiments cell monolayers grown in $60 \mathrm{~mm}$. Petri dishes were used. With plates of this size, inocula of $0 \cdot 1-0.5 \mathrm{ml}$. could be conveniently spread over the monolayer during the adsorption of RNA. Changes in volume within this range did not appear to have a significant effect on the RNA titre.

The titration of RNA was also unaffected by changes in the range $\mathrm{pH} \mathbf{7 \cdot 0} \mathbf{7} \cdot \mathbf{6}$, irrespective of the diluent used, but least cell damage was caused between $\mathrm{pH} \mathbf{7 \cdot 4}$ 
and 7.6. For this reason all the solutions used for washing monolayers and diluting the RNA were buffered within this pH range.

The method finally adopted for regular use was to treat the cells with hypertonic saline followed by the addition of the $\mathrm{RNA}$ in $2 \mathrm{M}-\mathrm{MgSO}_{4}$. The reproducibility of the method and the linearity of response between plaque number and dilution are

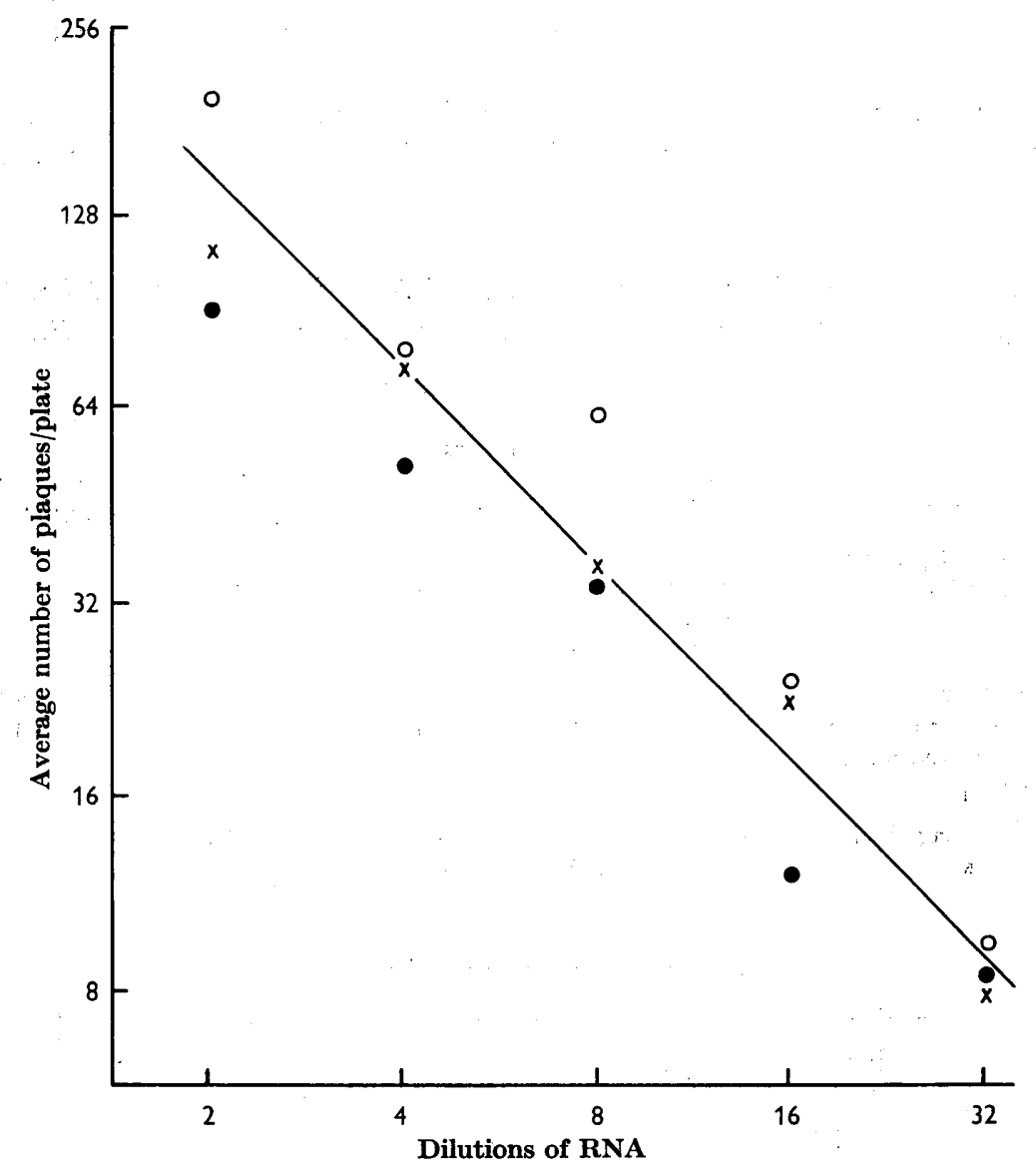

Fig. 1. Dose-response relationship for FMD-virus RNA (strain Turkey 43/62) on BHK 21 monolayers. Points were taken from three separate experiments.

shown in Fig. 1. Similar dose-response curves have been described for other infective RNAs (e.g. poliovirus RNA, Alexander et al. 1958; Koch et al. 1960; Holland et al. 1960 ; equine encephalitis-virus RNA, Colon \& Idoine, 1964) and for FMD-virus RNA, using calf kidney cells (Bachrach, 1960). Outside a 16-fold dilution range and plaque counts 160-10, plaque formation was no longer a linear function of the RNA dilution and at very low dilutions inhibition may occur. This may be due to the aggregation of the RNA in the presence of $2 \mathrm{M}-\mathrm{MgSO}_{4}$, as suggested by Holland $e$ al. (1960), or to inhibition by cellular DNA and RNA present in the extract (Franklin, Wecker \& Henry, 1959; Holland et al. 1960). The first possibility is contra-indicated in our system by the fact that RNA diluted in $2 \mathrm{M}-\mathrm{MgSO}_{4}$ could be held for up to 
$1 \mathrm{hr}$ at $0^{\circ}$ without apparent loss in titre. Inhibition at low dilutions becomes of practical importance only when examining RNA samples of low infectivity (e.g. after prolonged storage) and was much less marked when $2 \mathrm{M}$-sucrose or $\mathrm{M}-\mathrm{NaCl}$ was used as the diluent. Consequently, it was better to use one of these reagents for the titration of samples with low infectivity.

The plaque assay of FMD-virus RNA was compared with other methods of titration; typical results are presented in Table 2. The corresponding virus titrations are also given. For the strains used, the titres of RNA, but not always of virus, were equal to or higher than those obtained by in vivo methods. Consequently, it is misleading to express the RNA titre as a fraction of that of the intact virus without referring to the assay system used.

Table 2. Comparison of the plaque method for $F M D$ virus and its $R N A$ with other methods of titration. $\mathrm{RNA}$ extractions made with phenol saturated with $0.04{ }_{M-P O}, p H 7 \cdot 6$

\begin{tabular}{|c|c|c|c|c|}
\hline \multirow[b]{3}{*}{ Virus } & \multicolumn{4}{|c|}{ Assay system } \\
\hline & \multicolumn{2}{|c|}{ BHK monolayers } & \multirow{2}{*}{$\begin{array}{c}\text { Mice } \\
(\log \mathrm{ID50} / \mathrm{ml} .)\end{array}$} & \multirow{2}{*}{$\begin{array}{l}\text { Guinea pigs } \\
(\log \text { ID 50/ml.) }\end{array}$} \\
\hline & p.f.u./ml. & $\log \mathrm{ID} 50 / \mathrm{ml}$ & & \\
\hline $\begin{array}{l}\text { Turkey } 48 / 62 \text { passaged } \\
\text { in BHK cells }\end{array}$ & $\begin{array}{l}\text { Virus } 2.0 \times 10^{9} \\
\text { RNA } 2.3 \times 10^{5} \\
\text { Virus } 4.0 \times 10^{9} \\
\text { RNA } 4.4 \times 10^{5}\end{array}$ & $\begin{array}{l}9.5 \\
4.5 \\
- \\
-\end{array}$ & $\begin{array}{l}8 \cdot 8 \\
3 \cdot 3 \\
9 \cdot 1 \\
3 \cdot 1 \\
3 \cdot 3\end{array}$ & $\begin{array}{l}- \\
-\end{array}$ \\
\hline $\begin{array}{l}\text { Turkey } 43 / 62 \text { passaged } \\
\text { in guinea-pig plantar } \\
\text { pads extracted with } \\
\text { 0.04M-PO }\end{array}$ & $\begin{array}{l}\text { Virus } 4.5 \times 10^{7} \\
\text { RNA } 1.0 \times 10^{4}\end{array}$ & $\overline{3 \cdot 5}$ & $\begin{array}{l}9 \cdot 5 \\
4 \cdot 1\end{array}$ & $\begin{array}{l}\mathbf{5 \cdot 5} \\
\mathbf{3 \cdot 5}\end{array}$ \\
\hline $\begin{array}{l}\text { Strain } 1 \text { passaged in } \\
\text { BHK cells }\end{array}$ & $\begin{array}{l}\text { Virus } 9.4 \times 10^{7} \\
\text { RNA } 5.0 \times 10^{3}\end{array}$ & - & $\begin{array}{l}8 \cdot 2 \\
3 \cdot 5\end{array}$ & - \\
\hline
\end{tabular}

\section{Extraction procedures for $\boldsymbol{R N A}$}

In these experiments the procedure described by Brown \& Stewart (1959) was used as the standard method of RNA preparation with which other modifications were compared (Table 3). In contrast to Bachrach (1960), we found that the titres of RNA prepared with water-saturated phenol were somewhat lower than those of RNA prepared with buffered phenol, unless EDTA had been added. Since Bachrach (1960) had also reported that it was better to extract the RNA from solutions of low molarity, the effect of ionic strength on the extraction of FMD-virus RNA was then determined. We found that the titres of the RNA were unaltered by saturation of the phenol with $0.01 \mathrm{M}$ - or $0.04 \mathrm{M}$-phosphate or by the addition of $\mathrm{M}-\mathrm{NaCl}$ to the virus suspension before phenol treatment. These results, which were similar to those of Koch et al. (1960) with poliovirus RNA, suggested that ionic strength was of little importance during the extraction of FMD-virus RNA. Furthermore, despite the stabilizing effect of $\mathrm{M}-\mathrm{NaCl}$, there was no advantage in adding it to the virus suspension before extraction because the same effect could be achieved by the addition of $\mathrm{M}-\mathrm{NaCl}$ after phenol treatment. Moreover, when the phenol used for the extraction had been previously equilibrated with $\mathrm{M}-\mathrm{NaCl}$, difficulty was experienced in keeping the phenol in solution and in separating the two phases. 

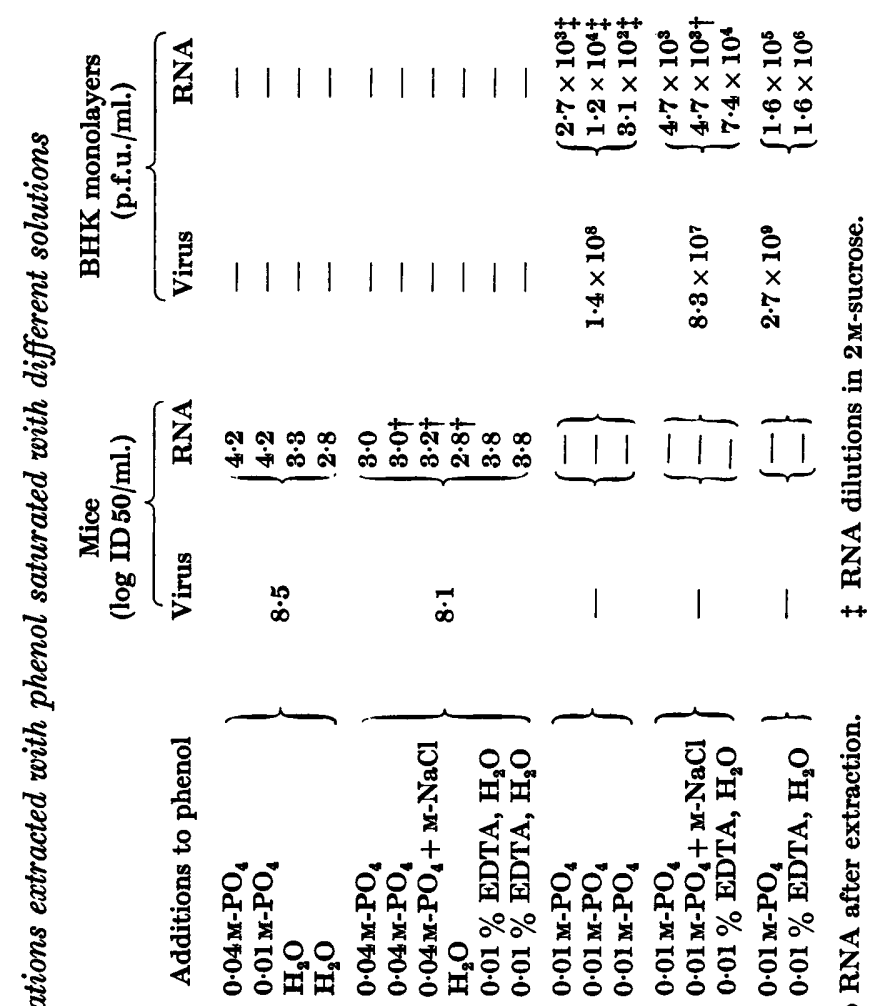

है

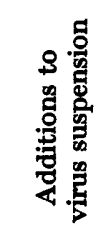

店

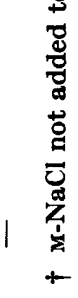

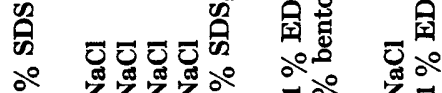

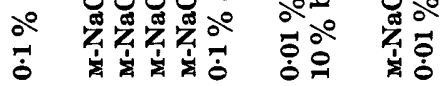

. त्र
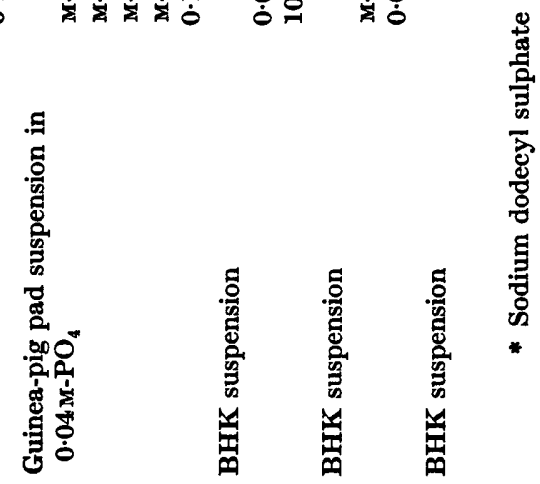
Consequently, the overall recovery was decreased although the titre of the RNA was unaltered.

Two other ribonuclease inhibitors, bentonite and SDS, were also used. Bentonite (Fraenkel-Conrat, Singer \& Tsugita, 1961), used in the preparation of FMD-virus RNA by Thely et al. (1961), was added to FMD virus suspensions before extraction with phenol saturated with phosphate. In every case the RNA titre was decreased. Unlike Bachrach (1960) we were unable to improve the RNA titres by adding sodium dodecyl sulphate to virus before extraction.

Following the results of Bachrach (1960) and Thely et al. (1961), the usefulness of EDTA in preparing FMD-virus RNA was examined. By the use of this reagent we were able to improve on Brown \& Stewart's (1959) method. We found that, when $0.01 \%$ EDTA in phosphate buffer ( $\mathrm{pH} \mathrm{7.6)}$ was added to the virus before extraction, the yield of RNA was often about ten-fold higher than that obtained by the standard procedure. It was equally effective to extract the virus with phenol saturated with $0.01 \%$ EDTA but increasing the EDTA concentration to $0.1 \%$ in either the virus suspension or the phenol was of no advantage. The phenol supernatant layer after equilibration with EDTA was between $\mathrm{pH} 4 \cdot 8$ and $5 \cdot 0$ but the RNA titres obtained were no higher when the phenol was also buffered in the usual way. The RNA extracts were in the range $\mathrm{pH} \mathbf{7 \cdot 0 - 7 \cdot 4}$ after ether treatment, in contrast to the values obtained when buffered phenol was used $(\geqslant 8 \cdot 0)$.

The technique finally adopted was to add EDTA to the virus suspension to a final concentration of $0.01 \%$ and to extract with phenol saturated with water containing the same concentration of the reagent. Even this method has at best produced only a ten-fold increase in RNA titre as compared with the standard procedure. This increased titre was presumably due to the stabilizing effect of EDTA on viral RNA first described by Fraenkel-Conrat (1957) for tobacco mosaic virus RNA and subsequently demonstrated for the RNAs of animal viruses by many authors (e.g. Ellem \& Colter, 1961). Its usefulness for the storage of RNA is discussed in the next section.

\section{Stability of infective $\boldsymbol{R N A}$}

Previous workers found that FMD-virus RNA is rapidly inactivated (e.g. Brown \& Stewart, 1959; Bachrach, 1960; Hantschel, 1963). The experiments described below were designed to find convenient methods for retaining infectivity during laboratory manipulations and prolonged storage. We found that even in the presence of $\mathrm{M}_{\mathrm{M}} \mathrm{NaCl}$ or $0.01 \%$ EDTA, FMD-virus RNA lost $99 \%$ of its infectivity in $24 \mathrm{hr}$ at laboratory temperatures. It seemed essential to store the RNA at lower temperatures and we investigated its stability at $4^{\circ}$ and $-20^{\circ}$. In some instances ribonuclease inhibitors (bentonite or $\mathrm{M}-\mathrm{NaCl}$ ) were used to minimize the effect of traces of the enzyme which are known to survive the phenol extraction. Storage in the presence of EDTA was also examined. All titrations were made by the plaque method.

At $4^{\circ}$ FMD-virus RNA could be stored successfully for several days provided that certain precautions were taken. The infectivity was lost within 3-4 days in the absence of EDTA, bentonite or $\mathrm{M}-\mathrm{NaCl}$ but when any of these reagents was added the process was somewhat slower, about $20 \%$ of the initial activity remaining after 7 days (Fig. 2). For periods up to 3-4 $\mathrm{hr} \mathrm{M}-\mathrm{NaCl}$ was useful to add to RNA extracts which did not contain EDTA. The most stable RNA preparations prepared in the 
presence of EDTA retained about $50 \%$ of the original activity after 7 days at $4^{\circ}$ and some activity was still detectable after 7 weeks. FMD-virus RNA prepared in the presence of EDTA was also the most stable at $-20^{\circ}$, but we were rarely able to achieve recoveries greater than $20 \%$ of the initial infectivity after 2 days and $10 \%$

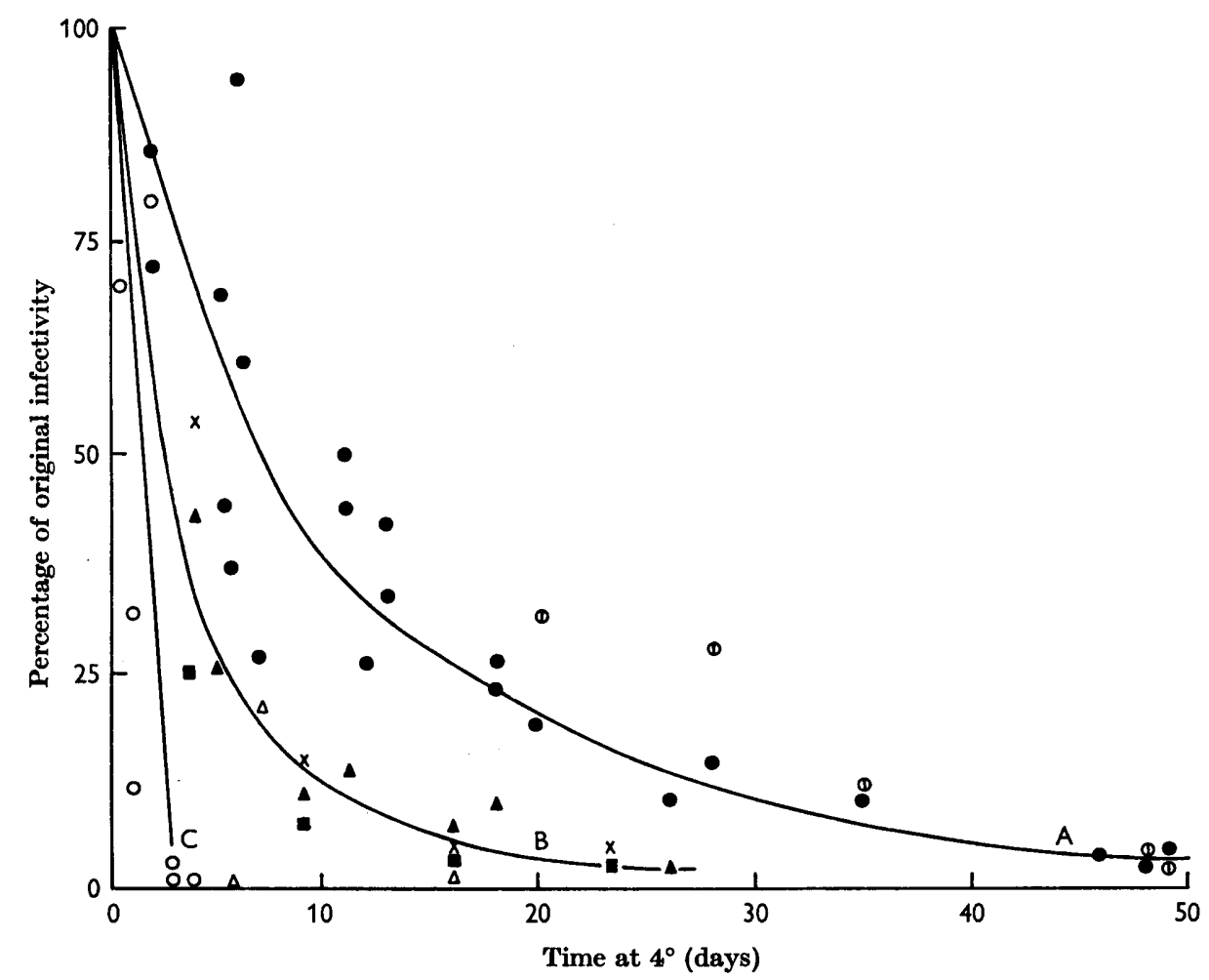

Fig. 2. Storage of FMD-virus RNA (strain Turkey $43 / 62$ ) at $4^{\circ}$. Results are taken from eight experiments with virus grown in BHK 21 cells. A, the decline of infectivity of RNA prepared in the presence of EDTA: (O) with and (D) without $\mathrm{M}-\mathrm{NaCl}$ added after extraction. $B$, the more rapid fall of infectivity of RNA prepared in the absence of EDTA but to which EDTA $(\Delta), \mathbf{M - N a C l}(\Delta), \mathbf{M}-\mathrm{NaCl}+\operatorname{EDTA}(x)$, or bentonite $(\square)$ were added before storage. $C$, the rapid decline of infectivity in RNA preparations which contained neither EDTA nor ribonuclease inhibitors $O$.

after 5 days at this temperature, although the residual infectivity did not decline significantly over a further 7 days (Fig. 3). Addition of $\mathrm{m}-\mathrm{NaCl}$ to preparations containing EDTA did not increase their stability at $4^{\circ}$ or $-20^{\circ}$.

The most effective method for preserving the infectivity was to add 2 vol. of ethanol and store at $-20^{\circ}$. With this method all the initial infectivity could be recovered up to 6 weeks later. For the prolonged storage of FMD-virus RNA this appears to be the method of choice, although storage at $4^{\circ}$ in the presence of EDTA is adequate for shorter periods. 


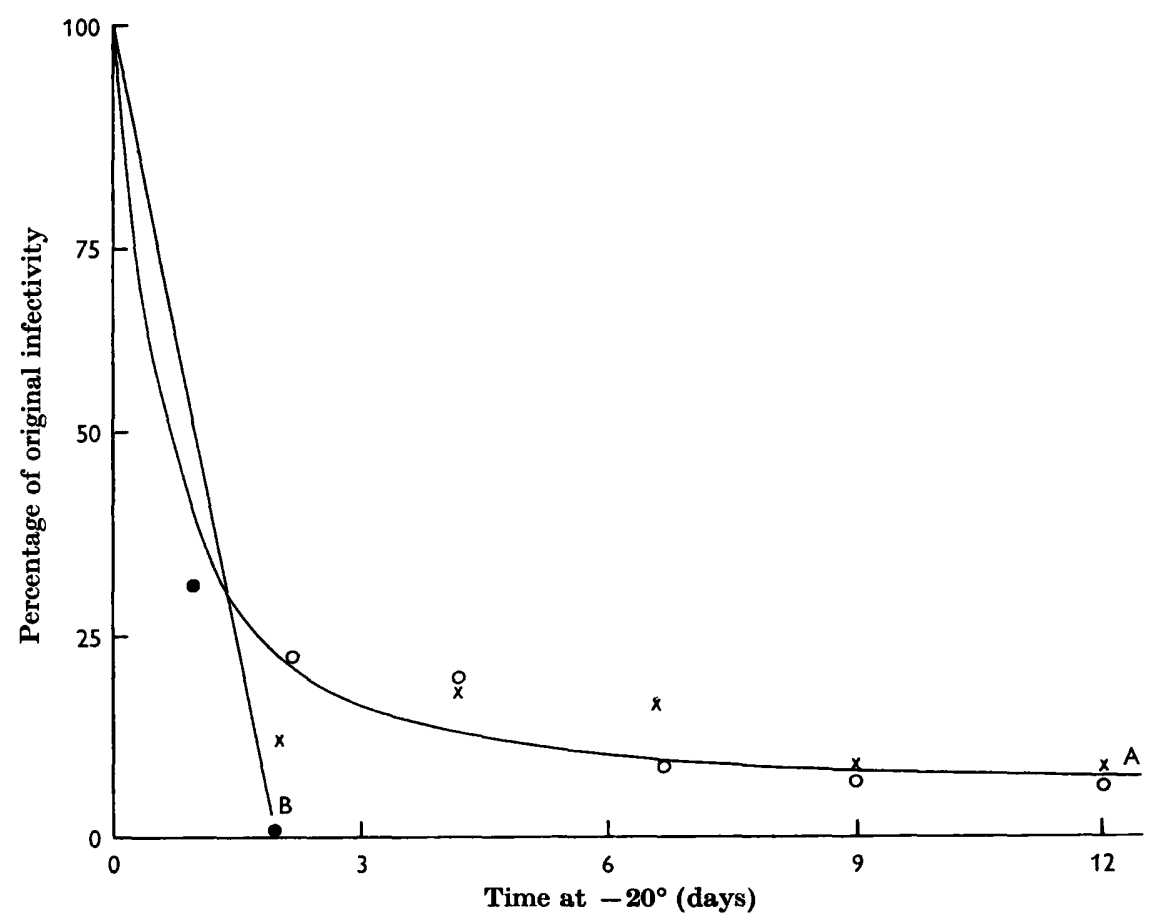

Fig. 3. Storage of FMD-virus RNA (strain Turkey 43/62) at $-20^{\circ}$. Results are taken from two experiments with virus grown in BHK 21 cells. A, the decline of infectivity of RNA prepared in the presence of EDTA: $(\times)$, with and (O), without $\mathrm{M}-\mathrm{NaCl}$ added after

extraction. B, the more rapid fall of infectivity of RNA prepared and stored in the absence of EDTA and $\mathrm{M}-\mathrm{NaCl}(\mathrm{O})$.

\section{DISCUSSION}

Although the RNA can be extracted from many viruses in almost quantitative yield, most workers agree that the infectivity of the extracts is usually only $0.1 \%$ or less of the infectivity of the virus suspensions from which they are prepared. Our best FMD-virus RNA titres were of this order, although the virus:RNA ratios are affected by the relative sensitivity of the assay system used for the virus and RNA respectively (Table 2). It appears therefore, either that the infective property of the FMD-virus RNA molecule is very easily damaged or that the infection of the cells is a much less efficient process than with the intact virus. With ${ }^{32} \mathrm{P}$-labelled FMD virus Brown \& Cartwright (1963) found that about $90 \%$ of the RNA is extracted from the virus by phenol and examination of this RNA by sucrose-density centrifugation showed it to be homogeneous, suggesting that all the molecules are potentially infective. The low infectivity may therefore be due to inefficiency in the process of infecting the cells. In our experiments with BHK monolayers less than $10 \%$ of the original activity was detected in the inoculum after 15-20 min. adsorption. This result might have been due to inactivation and not to adsorption of the RNA. It is difficult to exclude all traces of ribonuclease, and Norman \& Veomett (1961) showed that inhibitors of ribonuclease, such as $\mathrm{m}-\mathrm{NaCl}$, do not completely inhibit the action of the enzyme at the cell surface. Holland et al. (1960) 
and Sprunt et al. (1961) considered that the hypertonic solution used in the assay of poliovirus RNA played an active part in facilitating infection of cells by the RNA and did not act merely as a ribonuclease inhibitor. However, we have found that, although hypertonic conditions are necessary for the regular production of plaques by FMD-virus RNA in BHK cells, high salt concentrations were not essential for the initiation of infection. Cytopathic effects can be produced by the RNA in both BHK and pig kidney cells by using isotonic solutions and the titres given by this method in BHK cells are of the same order as those obtained by plaque assay. Furthermore, in contrast to Thomas \& Leclerc (1960), we were unable in these experiments to improve titres of RNA in guinea-pig pads by using $\mathrm{M}-\mathrm{NaCl}$ as the diluent instead of phosphate buffered saline. Therefore, the infection of cells by FMD-virus RNA, as opposed to the production of plaques, must be as efficient in isotonic as in hypertonic solutions. These results make the role of hypertonic solutions in the plaque assay of FMD-virus RNA even more difficult to interpret, but it seems probable that the low titres of the RNA were due to its inefficiency as an infecting agent rather than to its inactivation by ribonuclease at the cell surface.

The authors wish to thank Dr Z. Dinter for a preliminary discussion concerning the use of $2 \mathrm{M}-\mathrm{MgSO}_{4}$ as a diluent for RNA and $\mathrm{Mr}$ B. O. Underwood for considerable assistance.

Dr A. I. Lebedev of the All-Union Institute of Experimental Veterinary Science, Moscow, was a visiting worker under the U.S.S.R./Great Britain Cultural Exchange Scheme of the British Council for the year 1963/64.

\section{REFERENCES}

Alexander, H. E., Koch, G., Mountain, I. M. \& van Damme, O. (1958). Infectivity of ribonucleic acid from poliovirus in human cell monolayers. J. exp. Med. 108, 493.

BACHRACH, H. L. (1960). Ribonucleic acid of foot-and-mouth disease virus : its preparation, stability and plating efficiency on bovine-kidney cultures. Virology, 12, 258.

Brown, F. \& CARTwright, B. (1963). Purification of radioactive foot-and-mouth disease virus. Nature, Lond. 199, 1168.

Brown, F., Sellers, R. F. \& Stewart, D. L. (1958). Infectivity of ribonucleic acid from mice and tissue culture infected with the virus of foot-and-mouth disease. Nature, Lond. $182,535$.

Brown, F. \& Stewart, D. L. (1959). Studies with infective ribonucleic acid from tissues and cell cultures infected with the virus of foot-and-mouth disease. Virology, 7, 408.

Colon, J. I. \& IDoINE, J. B. (1964). Factors affecting plaque formation by the infectious ribonucleic acid of the equine encephalitis viruses. J. infect. Dis. 114, 61.

Ellem, K. A. O. \& Colter, J. S. (1961). The interaction of infectious ribonucleic acids with mammalian cells. III. Comparison of infection and RNA uptake in the HeLa cellpolio RNA and L cell-Mengo RNA systems. Virology, 15, 113.

Fraenkel-Conrat, H. (1957). The infectivity of tobacco mosaic virus nucleic acid. In Cellular Biology, Nucleic Acids and Viruses, p. 217. New York: New York Academy of Sciences.

Fraenkel-Conrat, H., Singer, B. \& Tsugtta, A. (1961). Purification of viral RNA by means of bentonite. Virology, 14, 54 .

Franklin, R. M., Wecker, E. \& Henry, C. (1959). Some properties of an infectious ribonucleic acid from mouse encephalomyelitis virus. Virology, 7, 220.

HANTSCHEL, H. (1963). Infektiöse Ribonukleinsäure aus neurotropem modifiziertem MKSTyp A. Arch. exp. Vet. Med. 17, 263. 
Hantschel, H. \& Veckenstedt, A. (1964). Infektiöse Ribonukleinsäure aus neurotropen Varianten des Maul-und-Klauenseuche-Virus. Arch. exp. Vet. Med. 18, 409.

Holland, J. T., Hoyer, B. H., Mclaren, L. C. \& Syverton, J. T. (1960). Enteroviral ribonucleic acid. I. Recovery from virus and assimilation by cells. J. exp. Med. 112, 821.

Koch, G., Koenig, S. \& Alexander, H. E. (1960). Quantitative studies on the infectivity of ribonucleic acid from partially purified and highly purified poliovirus preparations. Virology, 10, 329.

Macpherson, I. A. \& Stoker, M. G. P. (1962). Polyoma transformation of hamster cell clones-an investigation of genetic factors affecting cell competence. Virology, 16, 147.

Montagnier, L. \& Sanders, F. K. (1962). Titrage de l'acide ribonucléique infectieux du virus de l'encéphalomyocardite de la souris sur cellules d'ascite Krebs II in vitro. C. r. hebd. Séanc. Acad. Sci., Paris, 254, 2247.

Mowat, G. N. \& Chapman, W. G. (1962). Growth of foot-and-mouth disease virus in a fibroblastic cell line derived from hamster kidneys. Nature, Lond. 194, 253.

Mussgay, M. \& Strohmaier, K. (1958). Gewinnung eines infektiösen Prinzips von Ribonukleinsäure-Charakter aus Homogenaten mit dem Maul-und-Klauenseuche-Virus infizierter Jungmäuse. Zentbl. Bakt.ParasitKde (1. Abt. Orig.), 173, 163.

Norman, A. \& Veomett, R. C. (1961). Ribonuclease activity at the HeLa cell surface. Virology, 14, 497.

Reed, L. T. \& Muench, H. (1938). A simple method for estimating 50 per cent endpoints. Am. J. Hyg. 27, 493.

SkINNER, H. H. (1951). Propagation of strains of foot-and-mouth disease virus in unweaned white mice. Proc. R. Soc. Med. 44, 1041.

Sprunt, K., Koenig, S. \& Alexander, H. E. (1961). Factors influencing the infectivity of poliovirus ribonucleic acid. Proc. Soc. exp. Biol. Med. $108,755$.

Thely, M., SaCh, E., Dhennin, Léone, Choay, J. \& Dhennin, Louis (1961). Préparation à l'aide de la bentonite d'un acide ribonucléique hautement infectieux extrait d'epithélium lingual de bovins atteints de fièvre aphteuse. C. r. hebd. Séanc. Acad. Sci., Paris, 253, 3118.

Thomas, J. A. \& Leclerc, J. (1959). L'acide ribonucléique infectieux du virus de la fièvre aphteuse. C. r. hebd. Séanc. Acad. Sci., Paris, 248, 606.

Thomas, J. A. \& Lecherc, J. (1960). Sur le pouvoir infectieux et sur quelques propriétés de l'acide ribonucléique extrait du virus de la fièvre aphteuse. Bull. Off. int. Epiz. 53, 1328. 